Nurzaimah. et al. Improving Competitiveness Through Making Simple Cash Books For Business Tailor ...

\title{
IMPROVING COMPETITIVENESS THROUGH MAKING SIMPLE CASH BOOKS FOR BUSINESS TAILOR AND MIE REBUS / SATE
}

\author{
Case study on Palm oil Plantation PTPN IV Siantar
}

\author{
Nurzaimah, Mutia Ismail, Naleni Indra \\ Faculty of Economics and Business Universitas Sumatera Utara \\ Email : nurzaimah_ak@yahoo.com
}

\begin{abstract}
Devotion is done in Medan City and Lubuk Pakam,Sumatera Utara Province. Devotion takes the title "Training of Simple Cash Book Compilation for Multiple Small Medium Enterprises (SMEs)". Devotion to this community will be done for two householders from the preliminary survey who know that the housewives who do business behind this is the ability to perform activities that do not exist or simple cash bookkeeping do not know yet. The Community Service team will endeavor to assist the business partner on the basis of the difficulties it faces. Creating a better business. The target of mono community service activity this year is expected to develop business partner efforts that had been only staying at home so that will try to open the business of boiled noodles / satay then to sew can develop the seams. Many people will sew in their place.
\end{abstract}

Keywords : Improvement Through Bookkeeping Simple Cash Business Tailor and Boiled Noodles / Satay.

\section{INTRODUCTION}

\section{A. Situation Analysis}

Micro Small Medium Enterprises (MSMEs) is productive business owned by individual and or individual business entity that fulfill the criteria of micro business as regulated in the Law which has maximum assets of fifty million rupiah.

$\mathrm{UMKM}$ is a stand-alone productive economic enterprise conducted by an individual or a business entity that is not a subsidiary or a branch of a company owned, controlled, or becomes part of the direct or indirect business of a mediumsized or large-scale business that meets the criteria of a small business as referred to in the Act which has assets of fifty million up to five hundred million rupiah.

Understanding Small and medium enterprises can be seen from several aspects. In the Indonesian economy, the small and medium-sized business sector plays a very important role, especially when it is linked to the amount of labor that can be absorbed. Small and medium enterprises engaged in several business sectors including the agricultural sector, trade, mining, services and others whose role is no less important in moving the wheels of the economy in Indonesia.

Most of these SMEs are run by individuals without special expertise. SMEs run as it is and do not have a good financial system and financial management system. This is one of the weaknesses of SMEs, so they can not plan for future business development.

Based on the above, it is necessary to conduct community service activities, especially for SMEs about making a simple cash book and provide tricks in financial management. One of the Partners in this devotion is Business Tailor and Boiled Noodles, Sate.

\subsection{Literature review}

1. Simple Cash Bookkeeping

The accounting records on Small Business approach the bookkeeping system, with a single bookkeeping system. In a single book arrangement transactions that occur on Small Business can be recorded in the diaries and auxiliary books. The diaries record books on cash receipts, cash disbursements, sales, purchases, and 
Nurzaimah. et al. Improving Competitiveness Through Making Simple Cash Books For Business Tailor ...

memorials. Auxiliaries record accounts receivable, debt, and supplies. These books are in fact only a substitute for the names of the estimates (ledgers) in ordinary accounting (Single, 1997). Accounting records conducted by Small Business, among others, recording sales transactions, purchases, inventories, cash in, cash out, salary costs, others. Accounting reporting, including sales reporting, purchases, Profit and Loss, Changes in Equity, and Balance Sheet (Kurniawati et al., 2010). Not just companies that need bookkeeping, but private people need to do bookkeeping. Bookkeeping for the individual aims to know the amount of expenditure in a certain time, can also do financial planning in the future (Karyawati, 2008). Individuals, may not necessarily require excessively formal bookkeeping, but when an enterprise is established, it must begin to make regular and formal bookkeeping (Employee, 2008). Bookkeeping is done to find out how the resulting profit, operating costs, and sales in a certain period, the debt to be paid, and others. Recording is required to determine the progress of a business that can be used to control the condition of the business being run. Recording consists of various items that have their respective uses based on the purpose of manufacture, which are, among others, sales records, purchases, inventories, cash inflows, cash out, salary costs and other expenses (Kurniawati et al., 2010). Records made by Small Business include:

a) A sales note that records all sales transactions that occur. Serves to facilitate employees and managers in making sales reports that will be used to determine the profit generated, which is one element in making the Profit-Loss report (Kurniawati et al., 2010).

b) Purchase records that record all purchases that include purchase of goods to be sold. Serves to know the cost of a good. It is important to know in order to determine the selling price so as not to cause losses because the selling price is too low from the cost of goods (Kurniawati et al., 2010). c) The inventory record contains about the goods available plus the incoming goods minus the items that come out. This note serves to find out how much inventory the company has.

d) Cash entry is to record all cash receipts from sales. Useful to know how much cash the company has from the sales transaction.

e) Cash out record that records all cash expenses related to business purposes including debt repayment.

f) Record of salary expense ie record employee salary. Serves to assist the manager in checking how much the salary has been paid.

g) Records of miscellaneous expenses incurred in routine business operations such as water, electricity, telephone, and others.

\section{Sales}

Volume For each company the goal to be achieved is to maximize profit in addition to the company wants to keep growing. The realization of this goal is through steadyvolume sales because sales issues are the key to a company's success. In marketing activities the increase in sales volume is the sum of the sales activities of a product or service produced by the company in a given measure of time. The factors that influence the volume of peniualan by (Kotler, 2000: 55) include:

a) Selling price

Selling price factors are very important things and affect the sale of goods or services produced. Whether goods or services offered by the company can be reached by target consumers.

b) Product

The product of one of the factors affecting the level of sales volume as goods or services offered by the company whether in accordance with the level of consumer needs.

c) Promotional costs

Promotional costs are the activities of a company designed to provide information to persuade the other party about the company concerned and the goods and services offered.

d) Distribution channel 
Nurzaimah. et al. Improving Competitiveness Through Making Simple Cash Books For Business Tailor ...

It is a company activity to convey funds channeled goods offered by the company to the consumer that tested.

e) Quality

Quality and quality of goods is one of the factors that affect sales volume. With good quality then the consumer will remain loyal to the product of the company, and vice versa if utu products offered is not good then consumers will turn to other products. Each company has a particular design or design, it would be good if some of its unique properties distinguish it from other companies. The chance of a breakthrough or part of a competitive advantage in some way arises from the use of this power at the same time in design or design.

\subsection{Identification of problems}

From the preliminary survey results conducted by the team found there are some problems faced by business partners in developing their business, among others, is the partner does not have the equipment and equipment needed to support the business, the partner does not have a system of financial records and cash books, in business development.

\section{The proposed solution}

To solve the problems faced by our partners will provide assistance in the form of facilities and some necessary equipment, a simple Cash Book Making Training for partners, Business Motivation Training, and Income Revenue partner.

\section{OUTSIDE TARGET}

The target of mono community service activity this year is expected to develop business partner business. The significant outcome targets of community service activities are:

1. A simple cash-keeping method for partners

2. Increase sales volume

3. Improving the quality of the products produced

4. Improve customer satisfaction
5. Improved understanding and skills of the community

\section{ACTIVITY IMPLEMENTATION}

\section{A. Target Audience Between Strategic}

The target of this activity is the owner and all employees of Industrial Tailor and Seller Noodle Boiled / Sate.

\section{B. Linkage}

This devotion is done according to the application of the field of Accounting, also based on the consideration of the ease of the management and all employees of the Industry Tailor and Seller Noodle Boiled / Sate to carry out this activity.

\section{Method of Activity}

The method undertaken in this activity is training, which begins with the opening by members of devotion and welcome by the owner of the Tailor / Sate Noodle Tailor and Seller industry. After that, the chief of dedication to conduct a brief interview about the bookkeeping system that had been prepared by the owner. Then the training goes on to explain the simple bookkeeping system.

\section{Evaluation Design}

The evaluation undertaken in this training is the evaluation of learning outcomes that focus on changing knowledge and skills by providing exercises to measure the knowledge of owners and employees about the training materials. In accordance with the opinion of Cascio (2003), that evaluation of the results is a training evaluation that focuses on changes in knowledge, skills, attitudes, behavior and motivation. According to Aamodth (2007), evaluation of training outcomes that focus on knowledge change is done before and after the training.

Owners and carvivans are given training materials and are responsible for the training materials. 
Nurzaimah. et al. Improving Competitiveness Through Making Simple Cash Books For Business Tailor ...

\section{METHOD OF IMPLEMENTATION}

\section{A. Stages of Survey}

Review the location of dedication to the business partners of Squeezer and Seller of Boiled Noodles / Sate and identification of equipment needs to increase production of the object and chips.

\section{B. Stages of Implementation}

Implementation of service activities such as by giving and delivery of tools for the manufacture of Tailor and Noodle Squeeze / Sate.
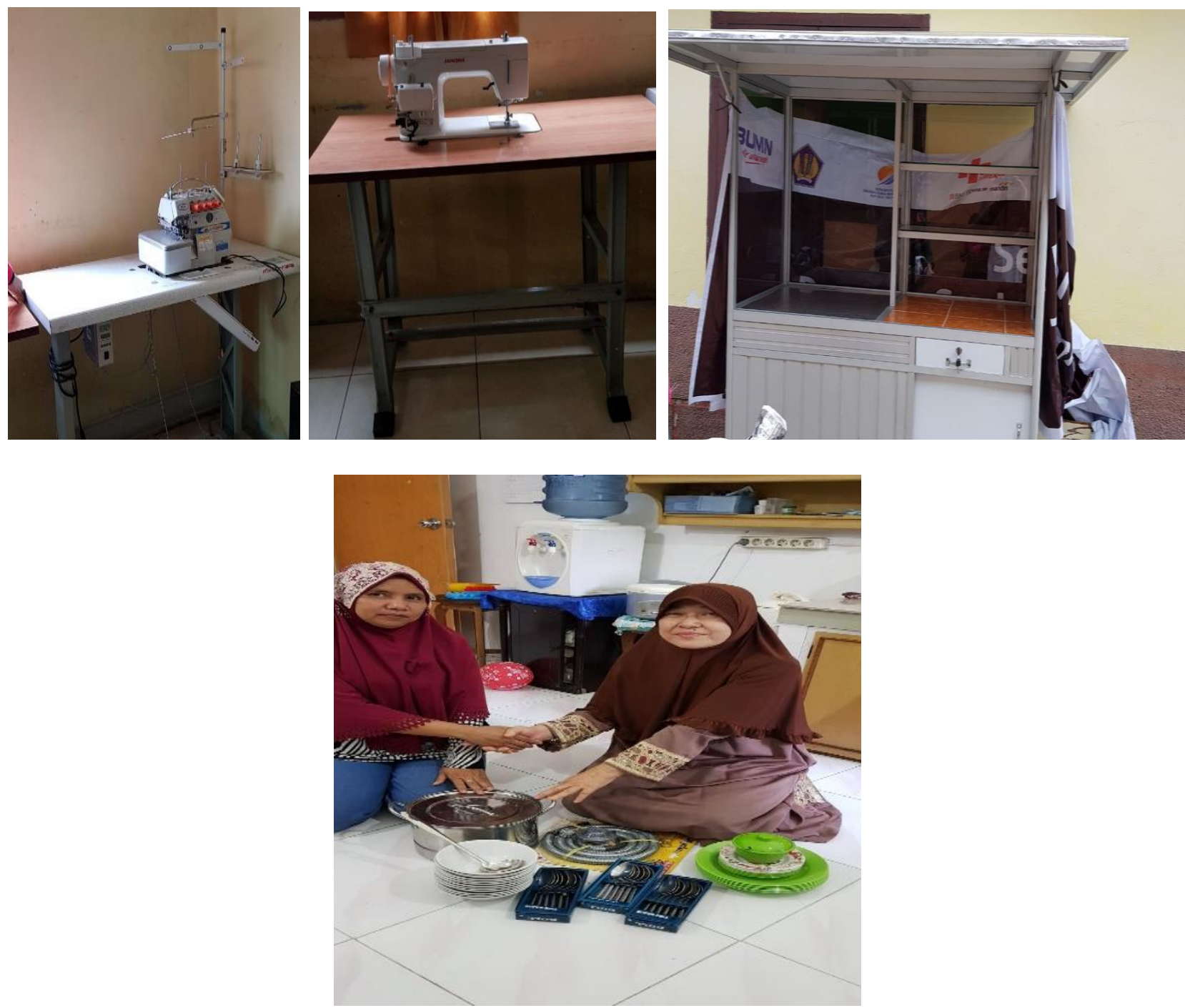
Nurzaimah. et al. Improving Competitiveness Through Making Simple Cash Books For Business Tailor ...

\section{Stages of Monitoring and Evaluation}

Mentoring and evaluation activities after the stages of implementation of service activities.

\section{THE RESULTS ACHIEVED}

Devotion to the Society of Business Partners Tailor and Seller Noodle Boiled / Sate has been implemented since May 2018. The activities that have been done are as follows:

1. Socialization will be held activities of dedication to the Community of Business Partners of chains and chips of the devotion team

2. Review of the location of the business premises and chips on both partners devotion

3. A review of venues for extension activities to partners of service

4. Identify the tools required by the partner of service

5. Preparing extension activities to the partner of service devotion products and Seller Noodle Boiled / Sate.

6. Conducting extension activities devotion Sewer and Seller Noodle Boiled / Sate:

a) Counseling for business motivation Tailor and Seller Noodle Boiled / Satay

b) Counseling sales volume

c) Giving the tools needed by the devotion partner

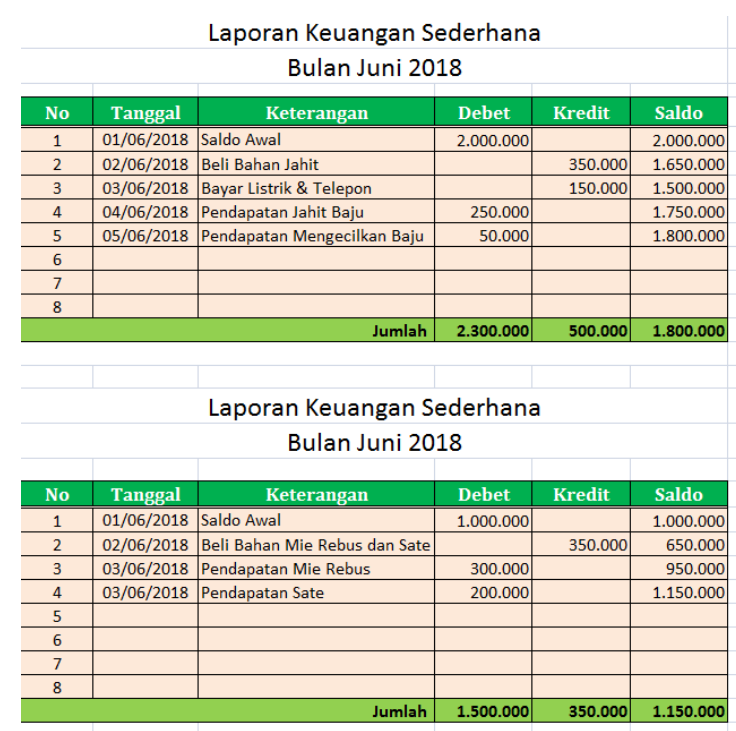

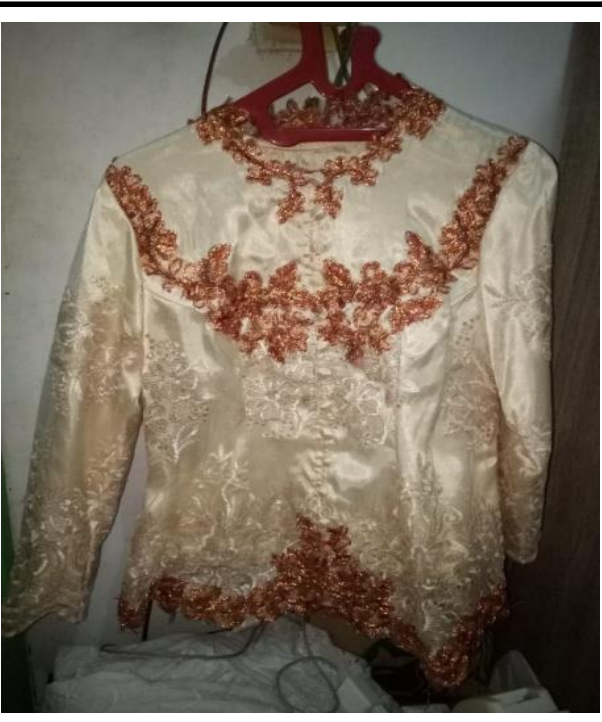
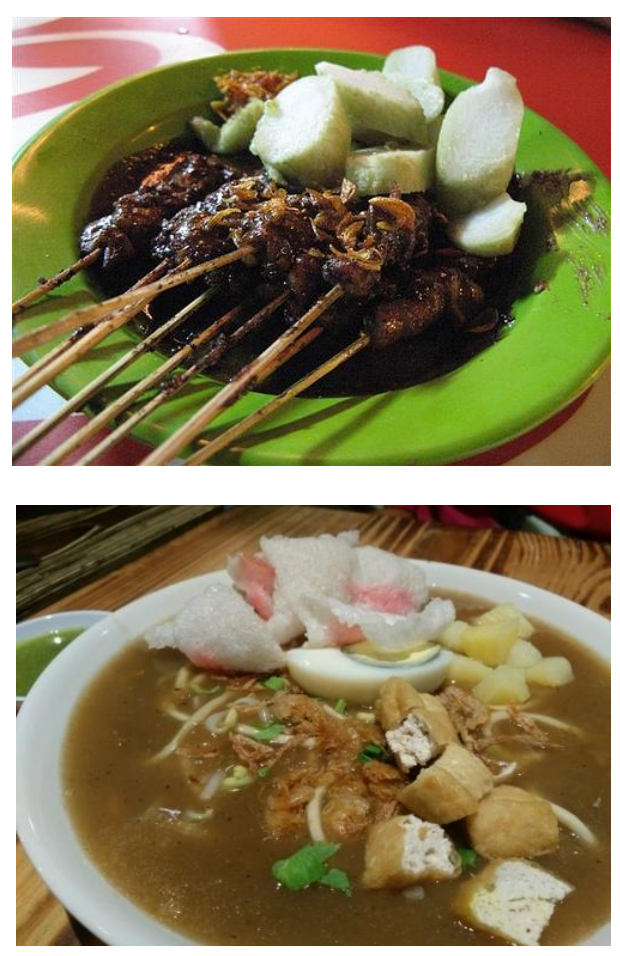

\section{CONCLUSIONS RECOMMENDATIONS}

AND

Community Service dedication to the business of Tailor and Boiled Noodles / Sate in Medan City has been able to run well and without any significant obstruction. With the cooperation of a team of good devotion and an active role in this devotional activity then everything has been running as expected and hope can provide benefits for business partners in sustainability. Our devotion has come to the final stage and for the next we want the 
Nurzaimah. et al. Improving Competitiveness Through Making Simple Cash Books For Business Tailor ...

business partners will be better again in the business.

\section{REFERENCES}

Benyamin, W. P., 1990, "Laporan Keuangan (Ikhtisar Akuntansi) Perusahaan Kecil" dalam Prosiding AkuntanNasional, Surabaya.

Karyawati, Golrida, 2008, Akuntansi Usaha Kecil Untuk Berkembang, PT RajaGrafindo, Jakarta.

Krisdiartiwi, Mamik, 2008, Pembukuan Sederhana untuk UKM, Media Pressindo, Yogyakarta.

Kuntatui, Fifid Afti, 2006, Identifikasi Pencatatan Akuntansi (Studi Kasus Pada Usaha Kecil Di Semarang).

Kurniawati, Elisabeth Penti, Paskah Ika Nugroho, dan Diyan Setiawati, 2010,
Penerapan Akuntansi Untuk Usaha Kecil dan Menengah (UKM) Studi Kasus Pada Usaha Dagang Kota Salatiga, Fakultas Ekonomika dan Bisnis Universitas Satya Wacana, Salatiga.

Kurniawati, Elisabeth Penti, dan Hermon Adhy Putra, 2012, Penyusunan Laporan Keuangan Untuk Usaha Kecil dan Menengah (UKM) Berbasis Standar Akuntansi Keuangan Entitas Tanpa Akuntabilitas Publik Warren, Carl S, James M. Reeve and Philip E. Fess, 2005, Pengantar Akuntansi, edisi 21, Salemba Empat, Jakarta.

Warsono, Sony, Arif Darmawan, dan M.Arsyadi Ridha, 2010. Akuntansi UMKM Ternyata Mudah Dipahami dan Dipraktikkan. Asgard Chapter Yogyakarta. 